\title{
Cancer mortality in ethylene oxide workers
}

\author{
L Bisanti, M Maggini, R Raschetti, S Spila Alegiani, F Menniti Ippolito, B Caffari, \\ N Segnan, A Ponti
}

\begin{abstract}
A cohort of 1971 chemical workers licenced to handle ethylene oxide was followed up retrospectively from 1940 to 1984 and the vital status of each subject was ascertained. No quantitative information on exposure was available and therefore cohort members were considered as presumably exposed to ethylene oxide. The cohort comprised 637 subjects allowed to handle only ethylene oxide and 1334 subjects who obtained a licence valid for ethylene oxide as well as other toxic gases. Potential confounding arising from the exposure to these other chemical agents was taken into consideration. Causes of death were found from death certificates and comparisons of mortality were made with the general population of the region where cohort members were resident. Seventy six deaths were reported whereas 98.8 were expected; the difference was statistically significant. The number of malignancies for any site exceeded the expected number (standardised mortality ratio $(\mathrm{SMR})=130 ; 43$ observed deaths; $95 \%$ confidence interval (95\% CI) 94-175) and approached statistical significance. For all considered cancer sites the SMRs were higher than 100 but the excess was only significant ( $p$ $<0.05$, two sided test) for lymphosarcoma and reticulosarcoma (International Classification of Diseases-9th revision (ICD-9) $=200$; SMR $=682$; four observed deaths; $95 \%$ CI 186-1745). The excess of cases for all cancers of haematopoietic tissue (ICD-9 $=200-208)$ also approached statistical significance $(\mathrm{SMR}=$
\end{abstract}

Regione Lombardia-Settore Sanità e Igiene Servizio di Epidemiologia e Sistema Informativo Via Stresa, 24-20125 Milano, Italy

L Bisanti

Istituto Superiore di Sanità, Laboratorio di Epidemiologia e Biostatistica, Viale Regina Elena, 299-00161 Roma, Italy

M Maggini, R Raschetti, S S Alegiani, F M Ippolito, B Caffari

Ospedale San Giovanni AS, Dipartimento Oncologico-Unità di Epidemiologia, Via San Francesco da Paola, 31-10123 Torino, Italy

N Segnan, A Ponti
250; six observed deaths; 95\% CI 91-544). Focusing the analysis on the subcohort of the ethylene oxide only licenced workers, who are likely to have experienced a more severe exposure to this gas, it became evident that all but one of the observed cases of haematopoietic tissue cancers in the cohort were confined to this subgroup, enhancing the relevant SMR to $700(95 \%$ CI 237-1637) and the SMR of lymphosarcoma and reticulosarcoma to 1693 (95\% CI 349-4953).

(British Journal of Industrial Medicine 1993;50:317-324)

Ethylene oxide is a gas often used in the chemical industry. It is an intermediate in the production of ethylene glycol, which is used in synthesis of antifreeze products, polyethylene fibres, and nonionic surface active agents. Ethylene oxide is also used as a sterilant for heat sensitive products such as hospital equipment, pharmaceutical products, foodstuffs, etc. It is also a fungicide in the fumigation of books, leather, tobacco, clothing, furs, furniture and other goods. The world production of ethylene oxide exceeds 5.5 million tonnes per year. ${ }^{1}$

Acute toxicity of this gas has been fully described, ${ }^{2}$ as well as its mutagenicity in vitro, ${ }^{3}$ in laboratory animals, ${ }^{4}$ and in humans. ${ }^{5}$ Its carcinogenicity has been shown in animal species. ${ }^{67}$

So far epidemiological evidence of carcinogenicity for ethylene oxide is contradictory. Four studies were published between 1979 and 1988 by Hogstedt et $a l^{8-11}$ who followed up cohorts of workers exposed to ethylene oxide. An almost ninefold increase in mortality from leukaemia and a fivefold increase in mortality from gastric cancer were the overall estimates of risk inferred by these studies. Exposure to ethylene oxide was estimated to be in the range of 5 to $20 \mathrm{ppm}$ and concomitant exposure to other known animal carcinogens could not be ruled out. Two negative studies were published, by Morgan et al $^{12}$ and by Thiess et al. ${ }^{13}$ Small sample size, poor information on exposure, and selection bias in the follow up affected the results of these studies. The potential cancer hazard of ethylene oxide became a matter of great controversy during the second half of the $1980 \mathrm{~s}^{14-16}$ and in 1987 the International Agency for Research on Cancer (IARC) assigned ethylene 
oxide to the sub-group $2 \mathrm{~A}$, meaning that this gas is probably carcinogenic to humans, because the evidence of carcinogenicity is sufficient in experimental animals but limited in humans. ${ }^{17}$ Gardner et al ${ }^{18}$ reported a non-significant excess of mortality from leukaemia and non-Hodgkin's lymphoma in a cohort of chemical and hospital workers exposed to ethylene oxide (standardised mortality ratio $(S M R)=189$; seven observed deaths; $95 \%$ confidence interval $(95 \% \mathrm{CI}) 76-390)$. In another cohort study of chemical workers at eight production plants in west Germany ${ }^{19}$ no difference in mortality from cancer of lymphatic and haematopoietic tissues was found between exposed and reference populations. An excess of mortality from leukaemia has been reported by Greenberg $e t a^{20}$ in a recent cohort study of chemical workers at three facilities in West Virginia where ethylene oxide was manufactured. The authors reported, however, that this excess was limited to the subcohort of workers also exposed to ethylene chlorohydrin. Finally, Steenland $e t$ al ${ }^{21}$ published the results of a mortality study on the largest cohort of workers exposed to ethylene oxide studied so far. No cause of death had a statistically significant excess; nevertheless sex specific analysis showed that men had a significant increase of deaths from haematopoietic cancers (SMR $=155 ; 27$ observed deaths) and lymphosarcoma and reticulosarcoma $(I C D-9=200 ;$ SMR $=260$; seven observed deaths).

The purpose of the present study was to investigate mortality from cancer among ethylene oxide workers in Italy, focusing in particular on cancer of lymphatic and haematopoietic tissue.

\section{Population and methods}

The adopted study design is a prospective nonconcurrent cohort study. All chemical workers who obtained a temporary licence for handling ethylene oxide in the period 1938-84 were considered. This source of enrolment into the cohort was selected partly to overcome difficulties related to the usually small sample size of the workforce in the chemical industries. Ethylene oxide belongs to a group of toxic gases for which a licence is compulsory by Italian law for all workers whose job entails the handling of one or more of the listed toxic gases (table 1). This law has been in effect since 1927; the licence is valid for a five year period and must be renewed if use is continued. A special commission is appointed to ascertain that the worker applying for the licence is in good physical condition and has an adequate knowledge of the specific hazards and current safety rules related to the toxic gases.

In this study being licenced for ethylene oxide is assumed to be a surrogate of exposure.

In two regions of northern Italy (Lombardia and Piemonte) complete rosters of licenced workers from
Table 1 List of toxic gases for which a licence is compulsory by Italian Law if handling them. The year of inclusion in the law and, for those evaluated for carcinogenicity, the IARC classifications are indicated

\begin{tabular}{lll}
\hline Gas & $\begin{array}{l}\text { Year of inclusion } \\
\text { in the law }\end{array}$ & $\begin{array}{l}\text { IARC } \\
\text { group }\end{array}$ \\
\hline Hydrocyanic acid & 1927 & \\
Ammonia (anhydrous) & 1927 & \\
Sulphur dioxide & 1927 & \\
Gasoline & 1927 & \\
Alkalic cyanides & 1927 & \\
Chlorine & 1927 & \\
Chloropicrin & 1927 & \\
Cyanogen & 1927 & \\
Cyanocarbon ether & 1927 & \\
Phosgene & 1927 & 3 \\
Isocyanocarbons & 1927 & $2 \mathrm{~A}$ \\
Ethylene oxide & 1927 & 3 \\
Tetraethyl lead & 1927 & \\
Carbon disulphide & 1927 & \\
Phosphine & 1939 & \\
Tetramethyl lead & 1961 & \\
Dimethyl sulphate & 1965 & \\
Methyl chloride & 1965 & \\
Hydrofluoric acid & 1969 & \\
Boron trifluoride & 1972 & \\
Methyl bromide & 1973 & \\
Methylmercaptan & 1974 & \\
Tetrahydrothiophene & 1978 & \\
Ethylmercaptan & 1978 & \\
Diethyl sulphide & 1978 & \\
Dimethyl sulphide & 1978 & \\
Ethyl isopropyl sulphide & 1978 & \\
\hline
\end{tabular}

1938 are available. Through these rosters it was possible to identify 2292 workers (1988 from Lombardia and 304 from Piemonte) who were licenced for ethylene oxide sometime between 1938 and 1984 . Only male workers were considered and, among them, only subjects who had had a licence for at least one year were included. Thus 1971 subjects were admitted to the cohort; 637 of them obtained a licence for ethylene oxide only and 1334 obtained a licence valid for ethylene oxide as well as for other toxic gases. The observation period lasted from 1 January 1940 to 31 May 1984.

Vital status of each cohort member at the end of follow up was assessed through the census office of the places of residence. Only 16 persons $(0.8 \%)$ were lost to follow up. For the computation of mortality figures, they were considered as still living at the end of the follow up period. The computation of the number of person-years at risk for each worker started one year after the licence was obtained.

Seventy six deceased subjects were identified, and their death certificates were obtained from the census offices of the respective place of residence. The International Classification of Diseases-9th revision (ICD code) of the underlying cause of death was gathered from the records of the Istituto Centrale di Statistica (ISTAT) for the 61 cohort members who died after 1969. The ICD code for the 15 deaths that occurred before that period was assigned by a qualified nosologist, strictly with the criteria in use at 
Table 2 Distribution of total person-years contributed by cohort members by age, time since the first exposure (latency), duration of exposure, and calendar period

\begin{tabular}{|c|c|c|c|c|c|c|}
\hline \multicolumn{2}{|l|}{ Age } & \multicolumn{2}{|c|}{ Latency } & \multirow{2}{*}{$\frac{\text { Exposure }}{6839}$} & \multicolumn{2}{|c|}{ Calendar period } \\
\hline$<25$ & 581 & 6839 & $<5$ & & $1940-4$ & 29 \\
\hline $25-34$ & 6002 & 5280 & 5- 9 & 8393 & 1945-9 & 49 \\
\hline $35-44$ & 6996 & 3431 & $10-14$ & 2496 & $1950-4$ & 103 \\
\hline $45-54$ & 4069 & 2090 & $15-19$ & 1181 & $1955-9$ & 385 \\
\hline $55-64$ & 1326 & 1098 & $20-24$ & 294 & $1960-4$ & 1123 \\
\hline $65-74$ & 279 & 379 & $25-29$ & 65 & $1965-9$ & 2104 \\
\hline$\geqslant 75$ & 15 & 151 & $30->$ & - & $1970-4$ & 3357 \\
\hline & & & & & $\begin{array}{l}1975-9 \\
1980-4\end{array}$ & $\begin{array}{l}4946 \\
7172\end{array}$ \\
\hline Total & 19268 & 19268 & & 19268 & & 19268 \\
\hline
\end{tabular}

ISTAT. This is a common practice in Italy, where individual death records on tape are available only from 1969. Nevertheless to check the consistency of this procedure, the underlying causes of deaths that occurred in the 1969-84 period were also blindly coded by the same nosologist and the respective codes compared with those assigned by ISTAT. No cancer death was coded as non-cancer or vice versa, but three (none of them was a haematopoietic cancer) out of 29 cancer deaths received different ICD codes.

Both national and regional (Lombardia) populations were used as reference groups but only comparisons with the regional population are presented since the results were similar adopting either reference group. (Data on the comparisons with the national population are available from the authors on request.)

The expected number of deaths was calculated by multiplying the person-years of observation within each five year age group during the respective calendar years of the study by the cause, sex and age specific death rates of Lombardia. The National Institute of Safety and Health life-table analysis system, ${ }^{22}$ adapted to the population of Lombardia, was used for the analyses. The $95 \%$ CIs of the SMRs were calculated assuming a Poisson distribution. Two sided significance tests were used for comparisons, to adopt a conservative procedure. Tests for trend in SMRs were conducted with the procedure described by Breslow and Day. ${ }^{23}$

\section{Results}

The total cohort contributed 19268 person-years. Table 2 shows the distribution by age, duration of exposure, time since the first exposure, and calendar period. Duration of exposure was estimated by the duration of the period during which the licence was

Table 3 Cause specific mortality in 1971 ethylene oxide licenced cohort members (1940-84): observed and expected deaths, $S M R$ standardised by sex, age, and calendar period on regional (Lombardia) population, and $95 \% \mathrm{CIs}$

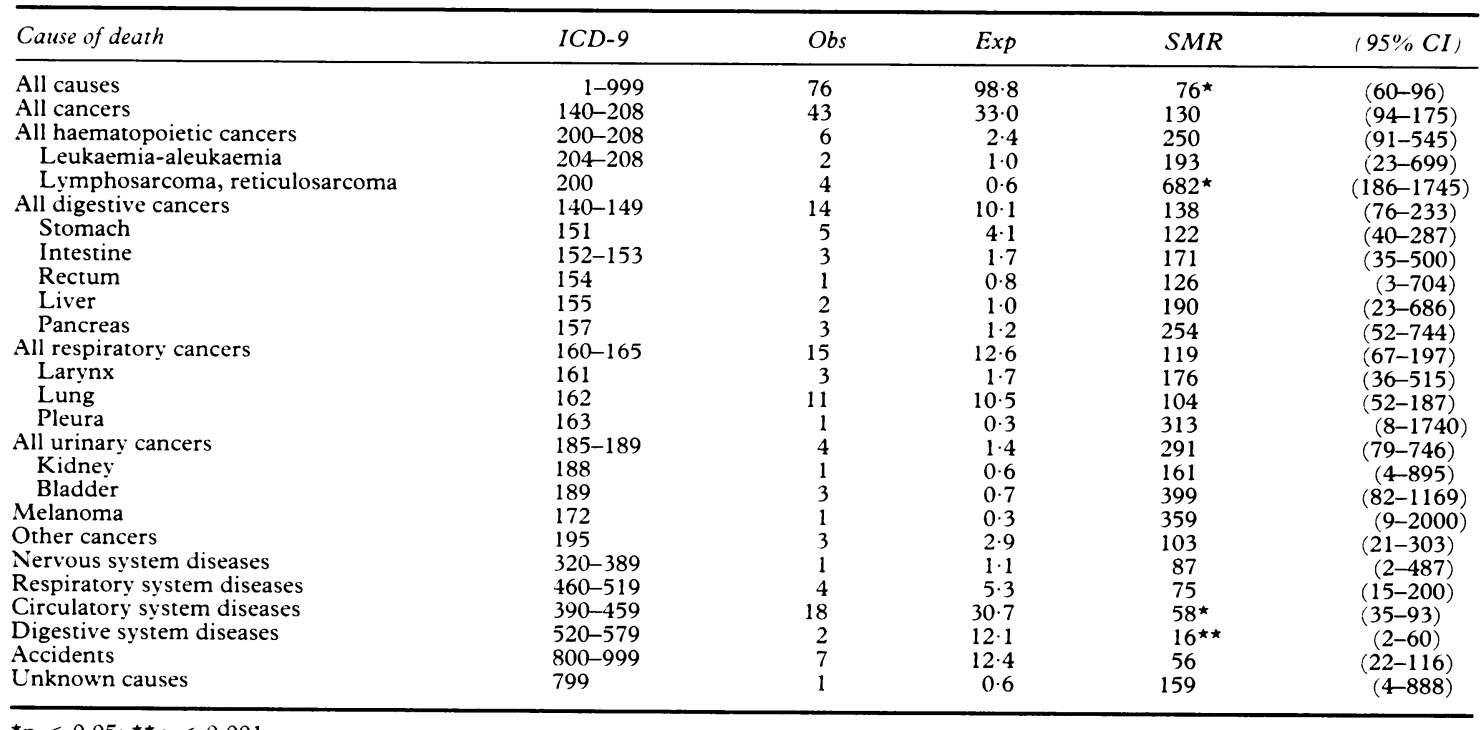

${ }^{\star} \mathrm{p}<0.05 ;{ }^{\star} \mathrm{p}<0.001$. 
Table 4 Distribution of SMRs and number of observed deaths (parentheses) for selected causes of death and cancer site by duration of exposure to ethylene oxide

\begin{tabular}{|c|c|c|c|c|c|}
\hline \multirow{3}{*}{$\frac{\text { Cause of death }}{\text { All deaths }}$} & \multicolumn{5}{|c|}{ Duration of exposure (y) } \\
\hline & $<5$ & \multicolumn{2}{|l|}{$5-9$} & \multicolumn{2}{|c|}{$\geqslant 10$} \\
\hline & 84 (14) & 79 & (36) & 71 & (26) \\
\hline All non-cancer deaths & $50 \quad(6)$ & 60 & (18) & 38 & (9) \\
\hline All cardiovascular diseases & $24 \quad(1)$ & 84 & (12) & 40 & (5) \\
\hline All cancers & $169 \quad(8)$ & 119 & (18) & 130 & (17) \\
\hline $\begin{array}{l}\text { All digestive cancers } \\
\text { Stomach } \\
\text { Intestine } \\
\text { Pancreas }\end{array}$ & $\begin{array}{rr}224 & (3) \\
380 & (2) \\
399 & (1) \\
- & (0)\end{array}$ & $\begin{array}{r}107 \\
53 \\
248 \\
-\end{array}$ & $\begin{array}{l}(5) \\
(1) \\
(2) \\
(0)\end{array}$ & $\begin{array}{l}147 \\
\frac{121}{629}\end{array}$ & $\begin{array}{l}\text { (6) } \\
(2) \\
(0) \\
(3)\end{array}$ \\
\hline $\begin{array}{l}\text { All respiratory cancers } \\
\text { Larynx } \\
\text { Lung }\end{array}$ & $\begin{array}{rr}124 & (2) \\
444 & (1) \\
75 & (1)\end{array}$ & $\begin{array}{l}121 \\
127 \\
103\end{array}$ & $\begin{array}{l}(7) \\
(1) \\
(5)\end{array}$ & $\begin{array}{l}116 \\
144 \\
114\end{array}$ & $\begin{array}{l}(6) \\
(1) \\
(5)\end{array}$ \\
\hline $\begin{array}{l}\text { All haematopoietic cancers } \\
\text { Lymphosarcoma and reticulosarcoma } \\
\text { Leukaemia-aleukaemia }\end{array}$ & $\begin{array}{ll}542 & (3) \\
781 & (1) \\
818 & (2)\end{array}$ & $\begin{array}{r}277 \\
1131 \\
-\end{array}$ & $\begin{array}{l}\text { (3) } \\
\text { (3) } \\
\text { (0) }\end{array}$ & $\bar{z}$ & $\begin{array}{l}(0) \\
(0) \\
(0)\end{array}$ \\
\hline
\end{tabular}

kept. Almost $50 \%$ of the cohort members entered the cohort after 1975 and therefore a large proportion of total person-years are distributed in exposure and latency periods shorter than 10 years.

Table 3 presents the distribution of the 76 observed deaths by groups of causes. A healthy worker effect is evident, particularly if cancer deaths in large excess are not considered. This effect seems to be mainly due to the deficit of deaths from heart diseases and non-malignant diseases of the digestive system (in particular liver cirrhosis: two observed and 9.7 expected deaths). The observed number of deaths exceeded the expected at any considered cancer site. This excess approached statistical significance for all haematopoietic cancers (six observed and 2.4 expected deaths) and reached statistical significance only for lymphosarcoma and reticulosarcoma (four observed and 0.6 expected deaths).

The trend of the SMRs by increasing duration of exposure (table 4) does not show a clear pattern; it is negative for all deaths and respiratory cancers, positive for lung cancer, and contradictory for most of the considered causes of death. Surprisingly, the trend of the SMRs by increasing time since the first exposure to ethylene oxide (table 5) is clearly negative for most of the considered causes of death.

Because two thirds of cohort members were holders of a licence valid for ethylene oxide as well as for other toxic gases, the possible confounding role of these agents was investigated by analysing the mor-

Table 5 Distribution of SMRs and number of observed deaths (parentheses) for selected causes of death and cancer site by time since first exposure to ethylene oxide

\begin{tabular}{|c|c|c|c|c|c|c|}
\hline \multirow{3}{*}{ Causes of death } & \multicolumn{6}{|c|}{ Latency $(y)$} \\
\hline & \multicolumn{2}{|l|}{$<10$} & \multicolumn{2}{|c|}{$10-19$} & \multicolumn{2}{|l|}{$\geqslant 20$} \\
\hline & 91 & $(32)$ & 76 & (27) & 60 & (17) \\
\hline All non-cancer deaths & 115 & (12) & 98 & (12) & 88 & (9) \\
\hline All cardiovascular diseases & 54 & $(5)$ & 72 & (8) & 48 & (5) \\
\hline All cancers & 192 & $(20)$ & 122 & (15) & 78 & (8) \\
\hline $\begin{array}{l}\text { All digestive cancers } \\
\text { Stomach } \\
\text { Intestine } \\
\text { Pancreas }\end{array}$ & $\begin{array}{r}232 \\
248 \\
550 \\
-\end{array}$ & $\begin{array}{l}(7) \\
(3) \\
(3) \\
(0)\end{array}$ & $\begin{array}{l}107 \\
132 \\
-224\end{array}$ & $\begin{array}{l}(4) \\
(2) \\
(0) \\
(1)\end{array}$ & $\frac{90}{534}$ & $\begin{array}{l}\text { (3) } \\
(0) \\
(0) \\
(2)\end{array}$ \\
\hline $\begin{array}{l}\text { All respiratory cancers } \\
\text { Larynx } \\
\text { Lung }\end{array}$ & $\begin{array}{l}191 \\
193 \\
165\end{array}$ & $\begin{array}{l}(7) \\
(1) \\
(5)\end{array}$ & $\begin{array}{l}144 \\
296 \\
123\end{array}$ & $\begin{array}{l}(7) \\
(2) \\
(5)\end{array}$ & $\frac{25}{29}$ & $\begin{array}{l}(1) \\
(0) \\
(1)\end{array}$ \\
\hline $\begin{array}{l}\text { All haematopoietic cancers } \\
\text { Lymphosarcoma and reticulosarcoma } \\
\text { Leukaemia-aleukaemia }\end{array}$ & $\begin{array}{r}464 \\
1188 \\
427\end{array}$ & $\begin{array}{l}(5) \\
(3) \\
(2)\end{array}$ & $\begin{array}{r}123 \\
489 \\
-\end{array}$ & $\begin{array}{l}(1) \\
(1) \\
(0)\end{array}$ & $\bar{z}$ & $\begin{array}{l}(0) \\
(0) \\
(0)\end{array}$ \\
\hline
\end{tabular}


Table 6 Cause specific mortality in 637 ethylene oxide only licenced cohort members (1940-84): observed (Obs) and expected (Exp) deaths, SMRs standardised by sex, age, and calendar period on regional (Lombardia) population, and $95 \%$ CIs

\begin{tabular}{|c|c|c|c|c|c|}
\hline Cause of death & $I C D-9$ & Obs & $\operatorname{Exp}$ & $S M R$ & $(95 \% C I)$ \\
\hline All causes & 1-999 & 27 & $30 \cdot 1$ & 87 & $(57-127)$ \\
\hline All cancers & $140-208$ & 15 & $10 \cdot 5$ & 142 & $(79-234)$ \\
\hline $\begin{array}{l}\text { All haematopoietic cancers } \\
\text { Leukaemia-aleukaemia } \\
\text { Lymphosarcoma, reticulosarcoma }\end{array}$ & $\begin{array}{l}200-208 \\
204-208 \\
200\end{array}$ & $\begin{array}{l}5 \\
2 \\
3\end{array}$ & $\begin{array}{l}0 \cdot 7 \\
0 \cdot 3 \\
0 \cdot 2\end{array}$ & $\begin{array}{l}700^{\star} \\
650 \\
1693^{\star \star}\end{array}$ & $\begin{array}{r}(227-1637) \\
(79-2349) \\
(349-4953)\end{array}$ \\
\hline $\begin{array}{l}\text { All digestive cancers } \\
\text { Stomach } \\
\text { Intestine } \\
\text { Rectum }\end{array}$ & $\begin{array}{l}140-149 \\
151 \\
152-153 \\
154\end{array}$ & $\begin{array}{l}3 \\
1 \\
1 \\
1\end{array}$ & $\begin{array}{l}3 \cdot 2 \\
1 \cdot 3 \\
0 \cdot 5 \\
0 \cdot 2\end{array}$ & $\begin{array}{r}92 \\
76 \\
179 \\
397\end{array}$ & $\begin{array}{c}(19-271) \\
(2-426) \\
(4-999) \\
(10-2208)\end{array}$ \\
\hline $\begin{array}{l}\text { All respiratory cancers } \\
\text { Lung } \\
\text { Pleura }\end{array}$ & $\begin{array}{l}160-165 \\
162 \\
163\end{array}$ & $\begin{array}{l}5 \\
4 \\
1\end{array}$ & $\begin{array}{l}4 \cdot 1 \\
3 \cdot 4 \\
0 \cdot 1\end{array}$ & $\begin{array}{l}122 \\
116 \\
990\end{array}$ & $\begin{array}{l}(39-286) \\
(32-298) \\
(25-5500)\end{array}$ \\
\hline Bladder cancer & 189 & 1 & $0 \cdot 2$ & 406 & $(10-2259)$ \\
\hline Other cancer & 195 & 1 & 0.9 & 111 & $(3-618)$ \\
\hline Nervous system diseases & $320-389$ & 1 & $0 \cdot 3$ & 289 & $(7-1610)$ \\
\hline Circulatory system diseases & $390-459$ & 7 & $9 \cdot 8$ & 71 & $(29-147)$ \\
\hline Accidents & $800-999$ & 4 & 3.5 & 114 & $(31-293)$ \\
\hline
\end{tabular}

${ }^{\star} \mathrm{p}<0.05 ;{ }^{\star \star} \mathrm{p}<0.001$.

tality data of all subcohorts of workers licenced for any but one of the listed toxic gases. This iterative procedure showed that site specific SMRs fluctuate in each subcohort but were consistent with those calculated for the entire cohort. (Detailed results of these analyses are available on request.)

To shed more light on the specificity of the association of exposure to ethylene oxide and mortality from cancer, a separate analysis of cohort members licenced for ethylene oxide only was conducted. Table 6 shows that the standardised mortality ratios of this subcohort were generally higher than those in the general cohort with the exception of the SMRs for all digestive cancers and stomach cancer. Five out of six observed cancers of lymphatic and haematopoietic tissue in the entire cohort were confined to the ethylene oxide only subcohort producing large SMRs, in particular for lymphoma and reticulosarcoma. Table 7 shows some characteristics of men who died from leukaemia and lymphosarcoma or reticulosarcoma. The mean age at death was 41.3 years, the mean duration of exposure was five years, and the mean time since first exposure was 5.5 years. Causes of death on the death certificates were centrally coded as: reticulosarcoma (three cases), lymphosarcoma, unspecified lymphoid leukaemia, and acute leukaemia of unspecified cell type.

\section{Discussion}

Two thirds of cohort members were holders of a licence valid for ethylene oxide as well as for other toxic gases. Nevertheless, we believe that the increased risk for cancer among the cohort members is less likely to be attributed to these other gases, although some interaction of the effects of these substances with ethylene oxide cannot be ruled out. These gases, indeed, are known to produce severe manifestations of acute toxicity but not to act as cancer causing agents. The International Agency for Research on Cancer evaluated the carcinogenicity of six gases out of the 27 listed in Italian law (table 1) and only ethylene oxide and dimethyl sulphate were considered as probably being carcinogenic to humans. Exposure to dimethyl sulphate was associated with lung cancer ${ }^{24}$ and with melanoma ${ }^{25}$ but not with cancer of lymphatic and haematopoietic tissue.

The finding that five out of six cases of cancer of lymphatic and haematopoietic tissue were confined to the subcohort of ethylene oxide only licenced workers provides indirect evidence of the postulated higher risk of cancer in subjects occupationally exposed to ethylene oxide. Indeed, even though documentation is lacking, it is likely that among the total ethylene oxide cohort, the workers who required and obtained a licence for handling ethylene oxide only had a job title primarily related to the production or use of this gas; on the other hand, the workers who kept a licence valid for a number of gases, including ethylene oxide, had a job title not specifically related to this gas but, rather, with 
Table 7 Characteristics of cohort members who died from lymphatic and haematopoietic tissue cancers

\begin{tabular}{|c|c|c|c|c|c|c|}
\hline \multirow[b]{2}{*}{$I C D-9$} & \multirow[b]{2}{*}{ Year of birth } & \multicolumn{2}{|c|}{ Time of first exposure to ethylene oxide } & \multirow{2}{*}{$\begin{array}{l}\text { Duration of } \\
\text { exposure }(y)\end{array}$} & \multirow[b]{2}{*}{ Latency $(y)$} & \multirow{2}{*}{$\begin{array}{l}\text { Age at } \\
\text { death }(y)\end{array}$} \\
\hline & & Year & Age $(y)$ & & & \\
\hline $208 \cdot 0$ & 1926 & 1958 & 32 & 2 & 2 & 34 \\
\hline $200 \cdot 0$ & 1937 & 1962 & 25 & 4 & 4 & 29 \\
\hline $200 \cdot 0^{\star}$ & 1933 & 1962 & 29 & 10 & 13 & 42 \\
\hline $200 \cdot 1$ & 1928 & 1968 & 40 & 5 & 5 & 45 \\
\hline 204.9 & 1936 & 1978 & 42 & 4 & 4 & 46 \\
\hline $200 \cdot 0$ & 1931 & 1978 & 47 & 5 & 5 & 52 \\
\hline
\end{tabular}

* The licence of this subject was valid for ethylene oxide and carbon disulphide. The other five subjects were licenced for ethylene oxide only.

various chemical agents. In this sense it has been assumed that: (1) a higher proportion of workers actually exposed to ethylene oxide was present in the first compared with the second subgroup and (2) the former group registered higher values of cumulative exposure to ethylene oxide.

The chemical workers in the ethylene oxide cohort were also exposed to cancer inducing agents other than the gases considered so far. Unfortunately, information on a quantitative basis is not available. It can be argued that the ethylene oxide only licenced workers experienced an actual exposure to this toxic agent whereas their exposure to other carcinogenic chemicals simply cannot be ruled out. On the contrary, the remaining cohort (those workers who kept a licence for several toxic gases, including ethylene oxide) presumably had a less severe and more intermittent exposure to ethylene oxide whereas their exposure to other carcinogenic chemical substances is more likely.

The reported excess of deaths in almost all cancer sites together with the large deficit of deaths in nonmalignant disease groups can hardly be attributed to a biased codification of death certificates for three reasons: (1) only a small proportion of ICD codes was not retrieved from the ISTAT mortality registry; (2) the validity of the code provided by an external nosologist was checked, and (3) the excess of cancer deaths from all sites is a common finding in mortality studies of chemical workers.
The distribution of site specific cancer deaths by duration of exposure and by time since the first exposure did not show any positive trend. It is disputable, however, whether the duration of licence use is a meaningful estimate of dose. Moreover, the absence of a dose response relation is important but not crucial to the determination of a causality of an association. ${ }^{26}$ Chance could be responsible for the negative trend of cancer SMR by latency, and a prolonged study period will shed more light on this point.

The occurrence of all cases of lymphatic and haematopoietic cancers within 10 years of latency is consistent with the tendency of this kind of tumour to appear in a shorter period compared with solid tumours, after the exposure to the causative agent. Assuming that carcinogenicity of ethylene oxide has a radiomimetic pattern, the excess of lymphatic and haematopoietic cancers should be evident within 10 years of initial exposure. ${ }^{27}$

In 1983, on the basis of the results of Swedish epidemiological studies, the Italian government lowered the standard for eight hour time weighted average exposure to ethylene oxide from $50 \mathrm{ppm}$ to 3 $\mathrm{ppm}$. Before that time, given the ignorance of long term effects of this gas, exposures to ethylene oxide are known to have exceeded the standard value. All cases of leukaemia and lymphosarcoma found in this study had had first exposure to ethylene oxide (obtained licence for the first time) by 1978 (table 7);

Table 8 Distribution of observed (Obs) and expected (Exp) deaths and SMRs by calendar period

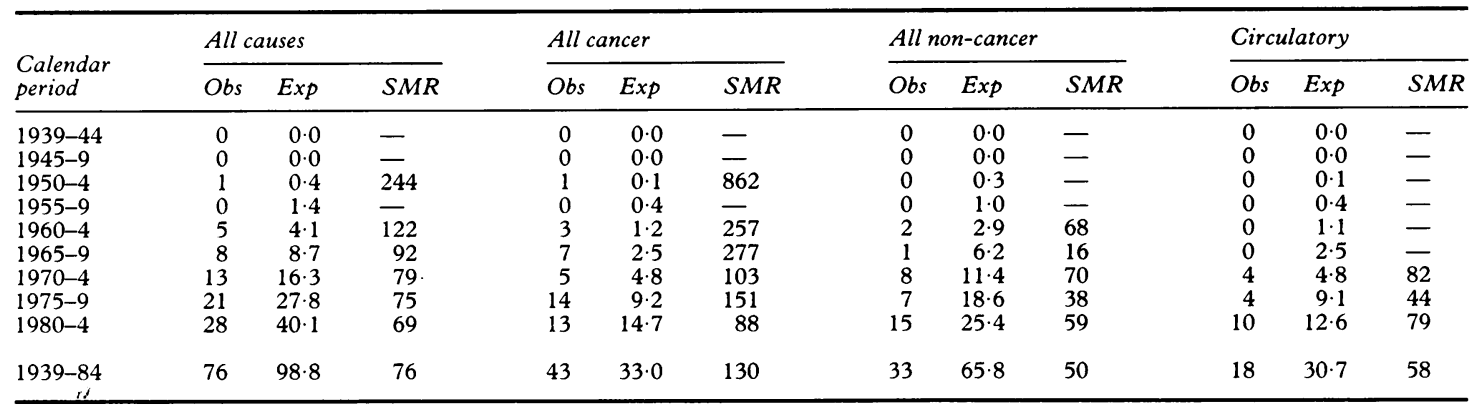


thus it is plausible that they have been severely exposed to ethylene oxide since that time or even earlier and this could provide an explanation of the short latency associated with these cases. Even though the law that makes the licence compulsory has been active since 1927 ethylene oxide workers have been pushed to submit for the licence when attention was paid to the possible carcinogenicity of this gas. Consequently, it is likely that a proportion of workers obtained the licence for the first time when the actual exposure had already started. It provides a further explanation of the short latency period.

The time distribution of person-years at risk (table 2) and cancer SMR by latency (table 5) could suggest some sort of bias. Removal of deceased workers from the registries and/or removal of workers licenced at an early stage of the observation period could account for both the small number of person-years during the 1940 s and 1950 s and the negative trend of SMR by latency. Actually it is unlikely that such a bias affected the study because the registries are filled in successively when the licence is issued and the record is fully independent of the future vital status of the worker. Furthermore five or more records are listed on each page of the registries and each record has a sequential identification code. Under these circumstances no removal of records could occur unnoticed. Production and use of ethylene oxide by the Italian chemical industries has had an exponential growth in the past decade. Only a few chemical workers were licensed during the 1940s and 1950s but some thousands were licensed later during the 1970s and 1980 s. This seems to be the most plausible explanation of the time distribution of person-years in this study.

As a systematic removal of old or "dead" records from the registries would correspond to very low SMRs in the early stage of the study period, the SMR of selected causes of death by calendar period were examined (table 8). Very high values for SMRs have been found in the early five year periods of observation when few deaths occurred but a low number of events was expected.

Mortality data have not been adjusted for smoking habits, because the relevant information was not available. It is worth noting, however, that this variable has not yet been reported as strongly associated with lymphosarcomas and leukaemia. Moreover, the cancer excess found could hardly be explained by an unlikely larger proportion of smokers among cohort members than in the general population. ${ }^{2829}$

Results of our study favour the suggested hypothesis of a higher risk of cancer in occupational exposure to ethylene oxide. In particular, we emphasise that the excess of cancers of lymphatic and haematopoietic tissue, statistically significant in this study, has been consistently found in most previous studies.
Nevertheless, given the adopted definition of exposure to ethylene oxide and the lack of information on the exposure to other industrial chemicals, our findings are not conclusive.

This study was partially supported by a grant (n 654/ 1985) from the Government of Regione Lombardia and a grant (n 223/1989) from the Government of Regione Piemonte.

Requests for reprints to: Luigi Bisanti, Regione Lombardia-Settore Sanità e Igiene, Servizio di Epidemiologia e Sistema Informativo, Via Stresa, 24, 20125 Milano, Italy.

1 National Toxicology Program. Toxicology and carcinogenesis studies of ethylene oxide, NTP TR 326. Washington DC: Government Printing Office, 1987. (NIH publ No 88-2582).

2 European Chemical Industry Ecology Toxicology Centre (ECETOC). Technical report No. 5. Toxicity of ethylene oxide and its relevance to man. Bruxelles: Ecetoc ed 1982.

3 Embree JW. Mutagenicity of ethylene oxide and associated health hazard (PhD thesis). San Francisco: University of California, 1975.

4 Cumming RB, Michaud TA. Mutagenic effects of inhaled ethylene oxide in male mice. Mutat Res 1979;1:166-7.

5 Galloway S, Barry P, Nicols W, et al. Chromosome aberrations in individuals occupationally exposed to ethylene oxide, and in a large control population. Mutat Res 1986;170:55-74.

6 Snellings WM, Weil CS, Maronpot RR. A two-year inhalation study of the carcinogenic potential of ethylene oxide in Fisher 344 rats. Toxicol Appl Pharmacol 1984;5:105-17.

7 National Toxicology Program. Toxicology and carcinogenesis studies of ethylene oxide (cas No 75-21-8) in BGC3F mice (inhalation studies). Research Triangle Park, NC: NTP; US Department of Health and Human Services, 1987. (Tech rep series No 326.)

8 Hogstedt C, Malmqvist N, Wadman B. Leukemia in workers exposed to ethylene oxide. $J A M A$ 1979;241:1132-3.

9 Hogstedt C, Rohlen O, Berndtsson BS, Axelson O, Ehrenberg L. A cohort study of mortality and cancer incidence in ethylene oxide production workers. Br J Ind Med 1979;36: 276-80.

10 Hogstedt C, Aringer L, Gustavsson A. Epidemiologic support for ethylene oxide as a cancer-causing agent. JAMA 1986; 255:1575-8.

11 Hogstedt C. Epidemiological studies on ethylene oxide and cancer: an updating. In: Bartsch $\mathrm{H}$, Hemminki $\mathrm{K}$, O'Neil I, eds. Methods for detecting DNA damaging agents in humans: applications in cancer epidemiology and prevention. (International Agency for Research on Cancer sci publ No 89). New York: Oxford University Press, 1988;89:265-70.

12 Morgan RW, Claxton KW, Divine BJ, Kaplan SD, Harris VB. Mortality among ethylene oxide workers. J Occup Med 1981; 23:767-70.

13 Thiess AM, Frentzel-Beyme R, Link R, et al. Mortality study on employees exposed to alkylene oxides (ethylene oxidepropylene oxide) and their derivatives. In: Prevention of occupational cancer. Occupational Safety and Health Series No 46. Geneva, International Labour Office, 1982:249-59.

14 Divine BJ, Amanollahi KS (letter). Hogstedt C (reply). Ethylene oxide and cancer. JAMA 1986;256:1726-7.

15 Hertz-Picciotto I, Neutra RR, Collins JF (letter). Ethylene oxide and leukemia. JAMA 1987;257:2290.

16 Austin SB (letter); Weiss H (letter); Collins JF, Neutra RR, Hertz-Picciotto I (reply). Carcinogenicity of ethylene oxide. JAMA 1987;258:1733-4.

17 International Agency for Research on Cancer. Overall evaluation of carcinogenicity: an updating of IARC monographs 1-42. Suppl 7. Lyons, France: International Agency for Research on Cancer, 1985.

18 Gardner MJ, Coggon D, Pannett B, Harris EC. Workers exposed to ethylene oxide: a follow-up study. $\mathrm{Br} J$ Ind Med $1989 ; 46: 860-5$.

19 Kiesselback N, Ulm K, Lange HJ, Korallus U. A multicentre 
mortality study of workers exposed to ethylene oxide. $\mathrm{Br} \mathrm{J}$ Ind Med 1990;47:182-8.

20 Greenberg HL, Otto MG, Shore RE. Men assigned to ethylene oxide production or other ethylene oxide-related chemical manufacturing: a mortality study. $\mathrm{Br} J$ Ind Med 1990;47: 221-30.

21 Steenland K, Stayner L, Greife A, et al. Mortality among workers exposed to ethylene oxide. New Engl J Med 1991; 324:1402-7.

22 Waxweiler RJ, Beaumont JJ, Henry JA, et al. A modified lifetable analysis system for cohort studies. $J$ Occup Med 1983;25:115-24.

23 Breslow NE, Day NE. The standardized mortality ratio. In: Sen PK, ed. Biostatistics: statistics in biomedical, public health and environmental sciences. North Holland: Elsevier Science Publishers, 1985:55-74.

24 Bettendorf U. Occupational lung cancer after inhalation of alkylating compounds. Dichlorodimethyl ether, mono- chlorodimethyl ether and dimethyl sulphate. Dtsch Med Wochenschr 1977;102:396-8.

25 Albert DM, Puliafito CA. Choroidal melanoma: possible exposure to industrial toxins. New Engl J Med 1977;296: 634-5.

26 Susser M. Falsification, verification and causal inference in epidemiology: reconsiderations in the light of Sir Karl Popper's philosophy. Epidemiology, Health and Society: selected assays. New York: Oxford University Press 1987:82-93.

$27 \mathrm{Kohn} \mathrm{HI,} \mathrm{Fry} \mathrm{RJM.} \mathrm{Radiation} \mathrm{carcinogenesis.} \mathrm{N} \mathrm{Engl} \mathrm{J} \mathrm{Med}$ 1984;310:504-11.

28 Axelson $O$. Aspects on confounding in occupational health epidemiology. Scand J Work Environ Health 1978;4:85-9.

29 Axelson O, Steenland K. Indirect methods of assessing the effects of tobacco use in occupational studies. Am J Ind Med 1988;13:105-18.

Accepted 13 July 1992

\section{Correspondence and editorials}

The British Journal of Industrial Medicine welcomes correspondence relating to any of the material appearing in the journal. Results from preliminary or small scale studies may also be published in the correspondence column if this seems appropriate. Letters should be not more than 500 words in length and contain a minimum of references. Table and figures should be kept to an absolute minimum. Letters are accepted on the understanding that they may be subject to editorial revision and shortening.

The journal now also publishes editorials which are normally specially commissioned. The Editor welcomes suggestions regarding suitable topics; those wishing to submit an editorial, however, should do so only after discussion with the Editor. 